\title{
Effect of polychlorophenols in sawdust bedding on some biotransformation parameters in the liver of mice
}

\author{
H. E. Falke and H. P. Til (TNO-CIVO Toxicology and Nutrition Institute. P.O. \\ Box 360, 3700 AJ Zeist, Netherlands)
}

Received 25 January 1985; accepted 9 May 1985

\begin{abstract}
The effect of polychlorophenols (PCP) in sawdust beddings on some biotransformation parameters in mouse liver was examined by keeping mice on beddings with low or high PCP content. A filter paper bedding was added for comparison.
\end{abstract}

Key-words: mice, liver, bedding, polychlorophenols, biotransformation.

Introduction. Sawdust is widely used as bedding material for small laboratory animals. Analyses of batches of softwood sawdust used in our institute showed the presence of varying levels of tri-, tetra- and pentachlorophenols. Technical grade pentachlorophenol may induce biotransformation enzyme activities in rat liver, probably due to the presence of impurities (Goldstein et al., 1977). Effects of 2,4,5trichlorophenol on biotransformation enzyme activities were observed in the liver of rats (Carlson, 1978) and mice (Kulkarni et al., 1980).

Animals kept on sawdust may be exposed to polychlorophenols (PCP) by ingestion and by dermal contact. Since this might affect the results of toxicity and carcinogenicity studies, we investigated the effect of housing mice on PCP-contaminated beddings on some biotransformation parameters in the liver.

Material and methods. Groups of twenty weanling male and female mice were housed on sawdust beddings with low $(<0.1 \mathrm{mg} / \mathrm{kg})$ or high $(74 \mathrm{mg} / \mathrm{kg})$ PCP content or on filter paper cuttings (PCP content $<0.3 \mathrm{mg} / \mathrm{kg}$ ). The PCP composition in the $74 \mathrm{mg} / \mathrm{kg}$ bedding was: $4.5 \mathrm{mg} / \mathrm{kg} \mathrm{2,4,6-tri-,} 0.1 \mathrm{mg} / \mathrm{kg} \mathrm{2,3,4,5-tetra-,} 50 \mathrm{mg} / \mathrm{kg}$ 2,3,4,6-tetra-, and $19 \mathrm{mg} / \mathrm{kg}$ pentachlorophenol. This batch was selected since it was representative of contaminated bedding material. On days 14 and 28 ten mice/ sex/group were killed by decapitation and the livers weighed and collected in icecold isotonic $\mathrm{KCl}$. The livers were homogenized with a Potter type homogenizer on ice and postmitochondrial fractions prepared by centrifugation at $9000 \mathrm{~g}$ for $15 \mathrm{~min}$ utes. In the homogenates glutathione (GSH) was determined (Sedlak \& Lindsay, 1968 ) and in the postmitochondrial fractions protein, cytochrome P-450 (P-450) (Schoene et al., 1972), aniline hydroxylase (AH) (Chhabra et al., 1972), aminopyrine N-demethylase (APDM) (Gram et al., 1968) and gamma-glutamyl transpeptidase (GGT) (Boehringer Mannheim GmbH, Kit No 125 954). Enzyme activities were expressed as $\mathrm{U} / \mathrm{kg}$ protein, $\mathrm{P}-450 \mathrm{as} \mu \mathrm{mol} / \mathrm{kg}$ protein and $\mathrm{GSH}$ as $\mathrm{mol} / \mathrm{kg}$ liver ( $1 \mathrm{U}=1 \mu \mathrm{mol}$ substrate converted per minute). The results were evaluated by analysis of variance, followed by Dunnetts test. 
Table. 1. Effects of bedding materials on biotransformation parameters in mouse liver (mean \pm standard deviation).

\begin{tabular}{|c|c|c|c|c|c|c|}
\hline \multirow[b]{2}{*}{ Bedding } & \multicolumn{3}{|l|}{ Day 14} & \multicolumn{3}{|l|}{ Day 28} \\
\hline & $\rightarrow-\mathrm{PCP}$ & $+\mathrm{PCP}$ & paper & $-\mathrm{PCP}$ & $+\mathrm{PCP}$ & paper \\
\hline \multicolumn{7}{|l|}{ Males } \\
\hline P-450 & $251 \pm 35$ & $217 \pm 56$ & $231 \pm 19$ & $212 \pm 28$ & $199 \pm 28$ & $185 \pm 38$ \\
\hline $\mathrm{AH}$ & $502 \pm 63$ & $497 \pm 111$ & $520 \pm 41$ & $546 \pm 66$ & $495 \pm 41$ & $454 \pm 38^{* *}$ \\
\hline APDM & $1450 \pm 221$ & $1300 \pm 316$ & $1210 \pm 126$ & $2040 \pm 126$ & $2100 \pm 158$ & $1780 \pm 221^{* *}$ \\
\hline \multicolumn{7}{|l|}{ Females } \\
\hline P-450 & $222 \pm 28$ & $202 \pm 28$ & $178 \pm 16^{* *}$ & $195 \pm 28$ & $173 \pm 22$ & $162 \pm 28^{*}$ \\
\hline $\mathrm{AH}$ & $548 \pm 86$ & $522 \pm 63$ & $512 \pm 54$ & $644 \pm 63$ & $631 \pm 54$ & $583 \pm 86$ \\
\hline APDM & $1430 \pm 126$ & $1420 \pm 158$ & $1360 \pm 158$ & $2390 \pm 442$ & $2410 \pm 285$ & $2200 \pm 379$ \\
\hline
\end{tabular}

${ }^{*} P<0.05,{ }^{* *} P<0.01$ compared to bedding without PCP.

Results. No differences were observed in absolute or relative liver weight among the groups in either sex. There was no difference between the high and low PCP bedding group, either in cytochrome $\mathrm{P}-450$ content or in aniline hydroxylase and aminopyrine $\mathrm{N}$-demethylase activities (Table 1 ). In the filter paper bedding group, however, females showed a lower cytochrome P-450 content on days 14 and 28 , and males showed lower aniline hydroxylase and aminopyrine $\mathrm{N}$-demethylase activities on day 28 when compared with the sawdust bedding groups. Gamma-glutamyl transpeptidase activity and glutathione content were comparable in all groups.

Discussion. This study did not reveal changes in the biotransformation enzyme system in the mouse liver that could be ascribed to the presence of $74 \mathrm{mg} / \mathrm{kg} \mathrm{PCP}$ in the sawdust bedding. However, the only PCP known to affect the hepatic biotransformation system, 2,4,5-trichlorophenol (Carlson, 1978; Kulkarni et al., 1980), was not present in the bedding material used. In comparison with filter paper bedding, both the contaminated and the uncontaminated sawdust beddings examined caused some enzyme induction in mouse livers. Apparently one or more components of the type of wood used are responsible for this effect. This is in agreement with the results of Vesell (1967) and Cunliffe-Beamer et al. (1981) who found that hexobarbital sleeping times and some hepatic enzyme activities in mice depended on the type of wood used for bedding. In our experiment the effect of keeping mice on sawdust beddings was sex-dependent. Sex-dependent effects on the mouse hepatic biotransformation system have been described by Govindwar et al. (1984) after treatment of mice with caffeine and by Wada et al. (1971) after adrenalectomy or castration. The reason for the increase in APDM activity from day 14 to day 28 is not clear, but might be related to the age of the mice. Since APDM activity represents only part of the total P-450 the absence of a similar increase in total P-450 is not surprising.

In conclusion it can be stated that in this particular batch of sawdust the presence of PCP did not affect the biotransformation parameters measured in this study. 
Sawdust itself, however, did show some effects on these parameters when compared to the paper bedding. It should be kept in mind that bedding material may interfere with the results of toxicity and carcinogenicity studies.

\section{References}

Carlson, G. P., 1978. Effect of trichlorophenols on xenobiotic metabolism in the rat. Toxicology 11: 145151 .

Chhabra, R. S., T. E. Gram \& J. R. Fouts, 1972. A comparative study of two procedures used in the determination of hepatic microsomal aniline hydroxylation. Toxicology and Applied Pharmacology 22: $50-58$.

Cunliffe-Beamer, T. L., L. C. Freeman \& D. D. Myers, 1981. Barbiturate sleeptime in mice exposed to autoclaved or unautoclaved wood beddings. Laboratory Animal Science 31: 672-675.

Goldstein, J. A., M. Friesen, R. E. Linder, P. Hickman, J. R. Hass \& H. Bergman, 1977. Effects of pentachlorophenol on hepatic drug metabolizing enzymes and porphyria related to contamination with chlorinated dibenzo-p-dioxins and dibenzofurans. Biochemical Pharmacology 26: 1549-1557.

Govindwar, S. P., M. S. Kachole \& S. S. Pawar, 1984. In vivo and in vitro effects of caffeine on hepatic mixed-function oxidases in rodents and chicks. Food and Cosmetics Toxicology 22: 371-375.

Gram, T. E., J. T. Wilson \& J. R. Fouts, 1968. Some characteristics of hepatic microsomal systems which metabolize aminopyrine in the rat and rabbit. The Journal of Pharmacology and Experimental Therapeutics 159: 172-181.

Kulkarni, A. P., D. L. Fabacher \& E. Hodgson, 1980. Pesticides as inducers of hepatic drug metabolizing enzymes II. Glutathione S-transferases. General Pharmacology 11: 437-441.

Sedlak, J. \& R. Lindsay, 1968. Estimation of total, protein bound, and nonprotein sulfhydryl groups in tissue with Ellman's reagent. Analytical Biochemistry 25: 192-205.

Schoene, B., R. A. Fleischmann, H. Remmer \& H. F. von Oldershausen, 1972. Determination of drug metabolizing enzymes in needle biopsies of human liver. European Journal of Clinical Pharmacology 4: $65-73$.

Vesell, E. S., 1967. Induction of drug-metabolizing enzymes in liver microsomes of mice and rats by softwood bedding. Science 157: 1057-1058.

Wada, F., M. Yoshida \& F. Isohashi, 1971. Effects of adrenalectomy and castration on enzymes metabolizing drugs in mouse. Journal of Biochemistry 71: 343-345.

This synopsis is based on a report entitled 'Effect of polychlorophenols in sawdust bedding on some biotransformation enzyme activities in the liver of mice', Division for Nutrition and Food Research TNO, Zeist, Netherlands, 1984. 40 pp., 2 figs., 8 tables, 12 refs., 7 appendices.

Available as paper copy (order R039P, $f 25$ including postage) or microfiche (order R039M, f 12.50 including postage) at: NARD, clo Pudoc, P.O. Box 4, 6700 AA Wageningen, Netherlands (telex 45015 blhwg $\mathrm{hl}$ ). 